\title{
A new insight into identification of in silico analysis of natural compounds targeting GPR120
}

\author{
Nagaraju Chinthakunta ${ }^{1}$. Srinivasulu Cheemanapalli ${ }^{1} \cdot$ Surekha Chinthakunta ${ }^{2} \cdot$ C. M. Anuradha ${ }^{3}$. \\ Suresh Kumar Chitta ${ }^{1}$
}

Received: 20 October 2017 / Revised: 6 April 2018 / Accepted: 7 April 2018 / Published online: 14 May 2018

(c) The Author(s) 2018

\begin{abstract}
G-protein coupled receptor (GPR120) is an omega-3 fatty acid receptor that inhibits macrophage-induced tissue inflammation. Recent studies revealed GPR120 promotes colorectal carcinoma through modulation of VEGF, IL-8, PGE2, and NF-kB expression. However, three-dimensional structure of GPR120 is not yet available in Protein Data Bank (PDB). In the present study, we focused on a 3-D structural model of GPR120 has been constructed using homology modeling techniques. The structural quality of the predicted GPR120 model was verified using Procheck, Whatif, ProSA, and Verify 3D. After this chemical database of natural compounds have been constructed and screened for its druggability using molinspiration server. Molecular docking studies of natural compounds on GPR120 model revealed that silibinin $(-6.87 \mathrm{kcal} / \mathrm{mol})$, withanolide $(-6.19 \mathrm{kcal} / \mathrm{mol})$, limonene $(-6.17 \mathrm{kcal} / \mathrm{mol})$, and cervical $(-6.15 \mathrm{kcal} / \mathrm{mol})$ have shown good docking interactions with active site residues of the target. Active site residues of Arg280, Asp275, and Gly122 showed hydrogen-bonding interactions with predicted compounds. Based on these in silico findings, we proposed that virtual screening of natural compounds against of GPR120 is a novel approach to find potential anti-colorectal cancer therapeutics.
\end{abstract}

Keywords Colorectal cancer · G-protein coupled receptor $120 \cdot$ Homology modeling natural compounds $\cdot$ Rule of five . Docking studies · Potential therapeutics

\section{Introduction}

Colon or colorectal cancer is a type of cancer that starts in the large intestine (colon) or the rectum (end of the colon). The origin of colon cancer is gastrointestinal tract of the epithelial cell lining present in the colon or rectum. Commonly mutations occur in the intestinal crypt cells (Ionov et al. 1993; Abdul Khalek et al. 2010). Colorectal cancer (CRC) is the third among most common malignancies worldwide (Shike et al. 1990) and the second leading cause of cancer deaths in the United States. It is

Suresh Kumar Chitta

suresh.chitta@ skuniversity.ac.in; chitta34c@gmail.com

1 Bioinformatics Infrastructure Facility, Department of Biochemistry, Sri Krishnadevaraya University, Anantapur, Andhra Pradesh 515003, India

2 Department of Botany, Rayalaseema University, Kurnool, Andhra Pradesh 518007, India

3 Department of Biotechnology, Sri Krishnadevaraya University, Anantapur, Andhra Pradesh 515003, India estimated that 132,700 new cases were diagnosed in the United States in 2015 and 49,700 deaths occurred due to this disease (American Cancer Society 2015). Better medication is still a significant cause of cancer-associated deaths. CRC is based on a complex of diseases arising from multistep process events in enterocytes, including genetic, epigenetic events, and abnormal signaling in basic cellular pathways. Thus, it is a hallmark of clinical value to identify potential molecules for tumor-preventive strategies (Roberta Bertorelle et al. 2014).

In G-protein-coupled receptors (GPCRs), ligands bind specifically to GPCRs to stimulate and induce a variety of cellular responses via several second messenger pathways; e.g., modulation of cyclic-AMP production, the phospholipase $C$ pathway, ion channels, and MAPK (Ulloa-Aguirre et al. 1999; Gether 2000; Schulte and Fredholm 2003). They are important signaling molecules for many aspects of cellular functions, including vision, olfaction, behavior, and autonomic transmission nervous system (Morris and Malbon 1999). Besides, they also regulate many characteristic features of tumorigenesis, including proliferation, 
invasion, survival at the secondary site, and immune cell function, as well as several cancer-associated signaling pathways (Feigin 2013). These properties permitted the widespread development of GPCR-targeted drugs, which represent nearly $30 \%$ of all currently used therapeutics (Lappano and Maggiolini 2011; Dorsam and Gutkind 2007). In particular, G-protein-coupled receptor 120 (GPR120), the most enigmatic member of this large family, has generated attention because of its potential role in the regulation of metabolic and inflammatory diseases such as obesity and type 2 diabetes.

G-protein coupled receptor 120 is a functional omega-3 FA receptor/sensor and mediates powerful insulin sensitizing and anti-diabetic effects by repressing macrophageinduced tissue inflammation (Oh et al. 2010). It is highly expressed in adipose tissue and proinflammatory macrophages, while activation of GPR120 affected LPS- and TNF- $\alpha$-induced inflammatory signaling responses (Oh et al. 2010; Ichimura et al. 2012). Activation of GPR120 signaling induced the expression and secretion of proangiogenic mediators of CRC cells which promoted the angiogenesis. The PI3K/Akt-NF-kB pathway is activated by GPR 120 signaling and required for GPR 120 signalinginduced angiogenic switching in CRC cells. Furthermore, GPR120 activation enhanced motility of CRC cells and induced epithelial-mesenchymal transition (EMT) of CRC cells (Wu et al. 2013).

There is an increasing demand for natural compounds that improve human health. The World Health Organization estimated that approximately $80 \%$ of the world's inhabitants rely on the traditional medicine for their primary health care (Farnsworth et al. 1985). Plants have long been used in the treatment of cancer (Hartwell 1971), and many nutritive and non-nutritive phytochemicals with diversified pharmacological properties have shown promising responses for the prevention and/or intervention of various cancers (Surh 2003), These products, especially phytochemicals, have been extensively studies and have exhibited anti-carcinogenic activities by interfering with the initiation, development, and progression of cancer through the modulation of various mechanisms including cellular proliferation, differentiation, apoptosis, angiogenesis, and metastasis (Rajesh et al. 2015). We focused on construction of GPR 120 model using in silico tools and refinement of structure by docking studies with natural compounds which are believed to help in understanding of structural features and the interactions of natural compounds with GPR 120 which may be helpful in designing of novel inhibitors of colorectal cancer.

\section{Materials and methods}

In the present study, all the calculations were performed in a workplace by AMD 64 bits dual processing hi end server machines. Molecular modeling tasks were performed with Modeller9v3; docking calculations were performed with AutoDock 4.0. Unless otherwise stated, default settings were used during all calculations.

\subsection{Sequence alignments}

All the analysis was carried out by AMD 64 bits dual processing hi end server machines. The sequence of G-protein coupled receptor120 (gi: 82581671) was obtained from the National Centre for Biotechnology Information (NCBI. http://www.ncbi.nlm.nih.gov/). Local alignments were predicted using Blastp (Basic Local Alignment Search Tool) (Altshul et al. 1997) at the NCBI and the homologous entries were obtained from the protein data bank (Berman et al. 2000). The Blastp alignment was further refined using sequence alignments in the Clustal W/X 1.83 with default parameters (Thompson et al. 1994).

\subsection{D model construction}

The Blastp alignment was used for homology modeling built in Modeller9v3 (http://www.salilab.org/modeller/9v3) which generated structures by applying spatial restraints. A bundle of 100 models from the random generation of the starting structure was calculated and subsequently the best model (with the low RMS value of superposition using Swiss-pdb viewer) (Guex and Peitsch 1997). To gain a better relaxation and much apart arrangement of the atoms, refinement was done on the built GPR 120 model by energy minimization (EM). The stabilization was assessed by graphics visualization.

\subsection{Evaluation of the homology model}

The stereochemical parameters of the energy minimized GPR120 model were assessed by Procheck (Laskowski et al. 1993), Whatif (Vriend 1990), Errat (Colovos and Yeates 1993), ProSA (Sippl 1993) and Verify 3D (Bowie et al. 1991; Luthy et al. 1992). Verify 3D was used to assess whether a primary sequence is compatible with the current 3D structural model. The compatibility between the amino acid side chains in the model is a validation criterion. Torsion angle restraints for the side chains of each amino acid in the predicted GPR120 model were determined using a 
Fig. 1 Multiple sequence alignment of GPR120 receptor and the template $4 \mathrm{~N} 6 \mathrm{H}$. Highly conserved residues are represented by as stars

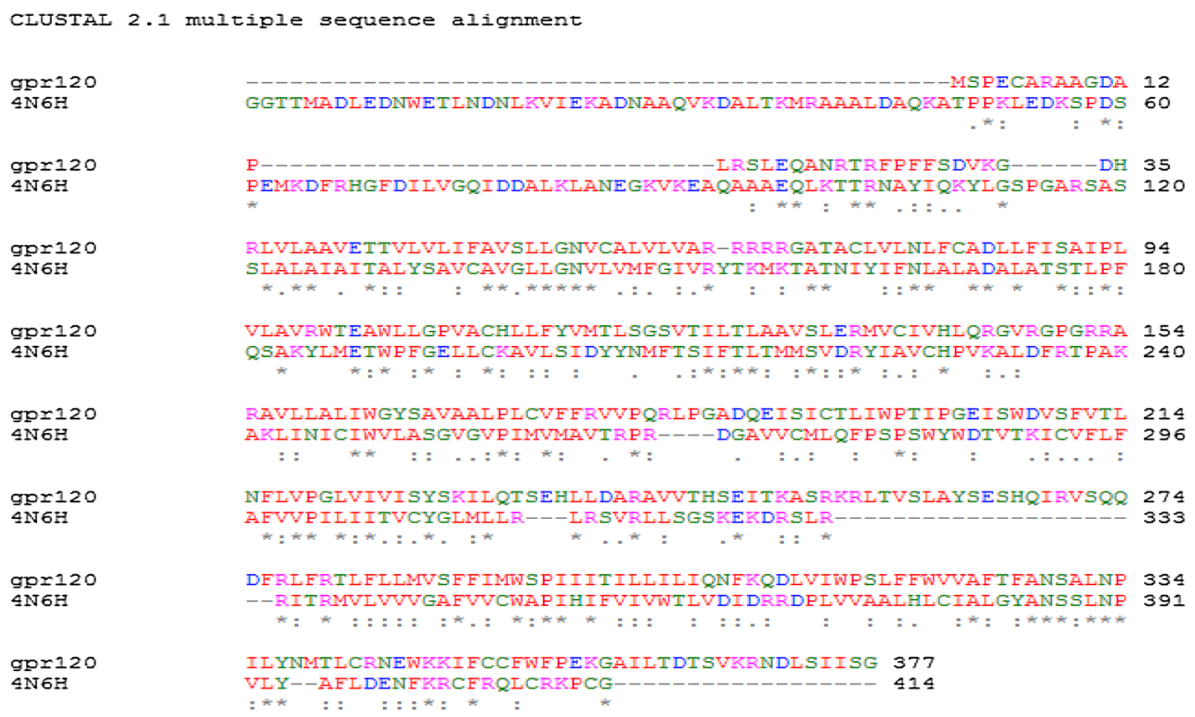

Web server Predictor (Berjanskii et al. 2006). The predictor assigns an error in the predicted chi $(\chi)$ torsion angle and including grains by combining its confidence scores with predicted or identified secondary structures and local sequence identity. Secondary structural conformations for the developed GPR120 model were predicted by Pdbsum (Laskowski et al. 2005).

\subsection{Docking studies}

\subsubsection{Selection and screening of natural ligands}

To fulfil the aim of constructing a novel ligand for GPR120, we selected a library of 100 molecules from the previous publications and browsing Internet. The selected library of ligands was tested for Lipinski's rule of five using molinspiration server (Lipinski et al. 2001) for their ability to follow the rule of five. Auto Dock 4.0/ADT (Goodsell and Morris 1998) program was used to investigate ligand binding to structurally refined GPR120 model using a grid spacing of $0.375 \AA$ and the grid points in $X, Y$, and $Z$ axis were set to $60 \times 60 \times 60$. The search was based on the Lamarckian genetic algorithm (Miyamoto and Kollman 1992; Oprea et al. 2001) and the results were analyzed using binding energy. For each ligand, a docking experiment consisting of 100 stimulations was performed and the analysis was based on binding-free energies and root-mean-square deviation (RMSD) values. Docking with natural Compounds was also performed onto GPR120 model with the same parameters and PMV 1.4.5 viewer was then used to observe the interactions of the docked compounds to the GPR120 model (Kitchen et al. 2004) and we submitted the developed 3D model of GPR120 to Protein Model Data Base (PMDB) (Castrignano et al. 2006), which maintains 3D models obtained by structure prediction methods.

\section{Results and discussion}

\subsection{Sequence alignments}

The coordinating 3D structure of Human Delta Opioid $7 \mathrm{tm}$ Receptor (PDB ID: 4N6H) (Fenalti et al. 2014). We found more than 70 crystallographic structures showing high identity score with respect to G-protein coupled receptor 120 using BLASTp results. We selected the Human Delta Opioid $7 \mathrm{tm}$ Receptor structure as template and the sequence identity
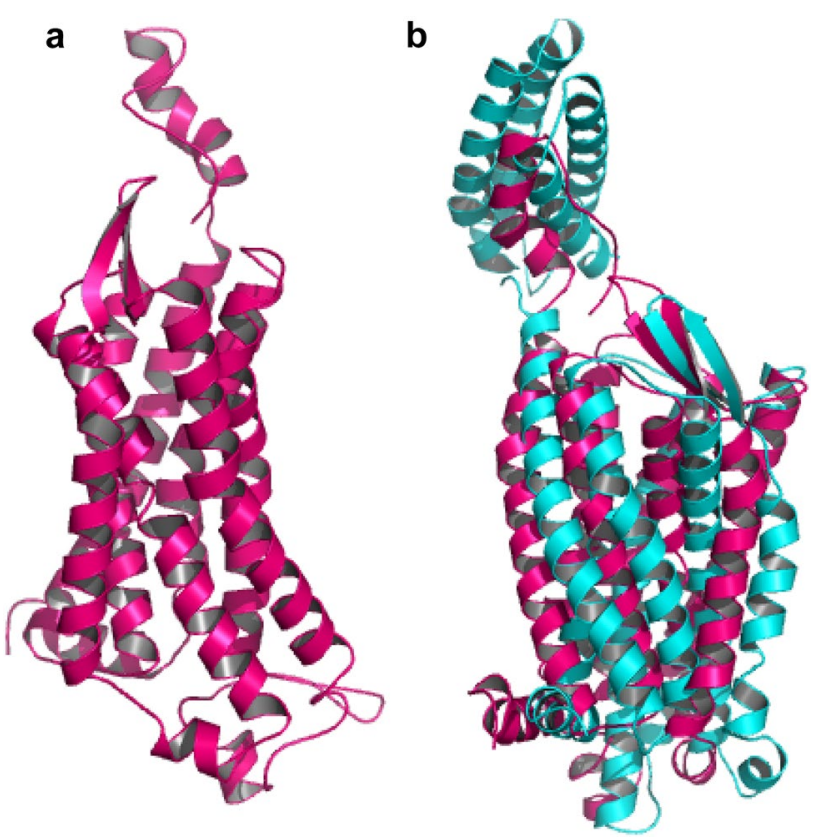

Fig. 2 a Predicted 3-D structure of GPR120 using Modeller 9v3. b Superimposed structures of GPR120 (hot pink) and 4N6H (cyan) 
between G-protein coupled receptor 120 and template $4 \mathrm{~N} 6 \mathrm{H}$ has $26 \%$ similarity having a resolution of $1.80 \AA$ A making it an excellent template. The most significant step in homology modeling process is to obtain the correct sequence alignment of the target sequence with the homologues. Finally, we performed an alignment between the selected template and the G-protein coupled receptor 120 using the ClustalX 1.8 with default parameters (Thompson et al. 1994). The sequence alignment performed homology modeling is shown in Fig. 1.
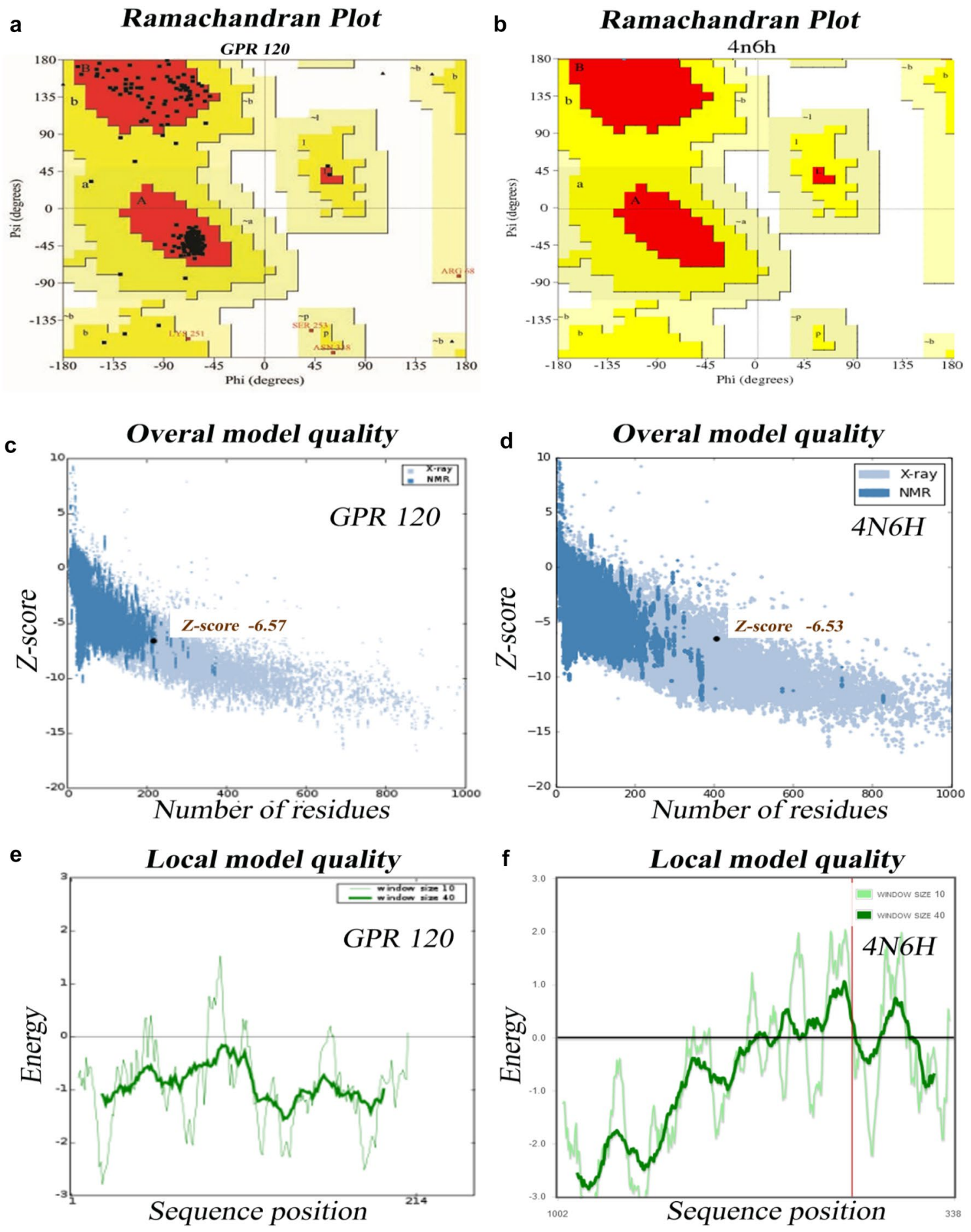

Fig. 3 a ProSA-web Z-scores of all protein chains in PDB determined by X-ray crystallography (light blue) and NMR spectroscopy (dark blue) with respect to their length. The Z-score of GPR120 present in that range represented in large black dot. b Energy plot for the predicted GPR120 


\subsection{Homology modeling}

The search using the BLASTp alignment algorithm within the PDB database showed various potential templates for molecular modeling purposes. More than 70 crystallographic structures showed high identity score with and maximum query coverage respect to G-protein coupled receptor. The coordinates of the crystal structures of Human Delta Opioid 7tm Receptor (PDB ID: 4N6H) (Castrignano et al. 2006) were used as a template to build the structure of G-protein coupled receptor 120. The 3D models of the G-protein coupled receptor 120 were built by Modeller 9v3. One hundred models were generated and the crystal structure of the template was saved for further refinement and validation (Fig. 2a, b). Furthermore, refinement was performed to obtain the best conformation of the developed model of G-protein coupled receptor 120.

\subsection{Structural validation of developed model}

The constructed model was subjected to validation using Ramachandran plot with Procheck program by checking the detailed residue-by-residue stereochemical quality of a protein structure (Laskowski et al. 1993). The Ramachandran plot revealed that $100 \%$ of the residues in homology model were in favored and allowed regions. The main structural elements of the optimized GPR120 homology model are shown in Fig. 3. In comparison with the templates, the homology model had a similar Ramachandran plot with $0.0 \%$ residues in disallowed regions. The total quality G-factor was -0.1 , which indicates a good quality model (acceptable values of the G-factor in Procheck are between 0 and -0.5 , with the best models displaying values close to zero) showed in (Table 1). The Errat is a so-called "overall quality factor" for non-bonded atomic interactions and higher scores mean higher quality (Sippl 1993). The normally accepted range is $>50$ for a highquality model (Colovos and Yeates 1993). In the current case, the Errat score for the GPR120 model is 54.366, which well within the range of a high-quality model.

Table 1 Ramachandran plot statistics

\begin{tabular}{lrr}
\hline Residues in most favored regions & 328 & $95.1 \%$ \\
Residues in additional allowed regions & 13 & $3.8 \%$ \\
Residues in generously allowed regions & 4 & $1.2 \%$ \\
Residues in disallowed regions & 0 & $0.0 \%$ \\
Number of non-glycine and non proline residues & 345 & $100.00 \%$ \\
Number of end-residues (excl. Gly and Pro) & 1 & \\
Number of glycine residues (shown as triangle) & 15 & \\
Number of proline residues & 16 & \\
Total number of residues & 377 & \\
\hline
\end{tabular}

Analysis of the energy minimized GPR120 model with Whatif web interface (Vriend 1990) revealed that RMS $\mathrm{Z}$-Scores for bond angles and bond lengths are all close to 1 and also within the limits of template. Detailed structural investigation of the predicted GPR 120 model with Pdbsum, a secondary structure prediction server, revealed that $225(59.7 \%)$ residues are in $\alpha$-helices and $3(0.8 \%)$ residues are in 3-10 helix and 137 (36.3\%) residues are in other conformations (Fig. 4, Laskowski et al. 2005). The tertiary structure of GPR 120 showed close similarity to crystallized $4 \mathrm{~N} 6 \mathrm{H}$, with a backbone RMS value of GPR120-4N6H, is between 0.58 and $0.72 \AA$, respectively. The low RMS values for backbone superposition reflect the high structural conservation of this complex through evaluation, making it a good system for homology modeling.

\subsection{Screening and docking studies of natural inhibitors of GPR120}

Docking is frequently used to predict the binding orientation of small molecule drug candidates to their protein targets to predict the affinity and activity of the small molecule. Hence, docking plays an important role in the rational design of drugs (Kitchen et al. 2004). Docking studies were performed to gain insight into the binding interaction between constructed model of GPR120 and selected 100 natural compounds.

\subsubsection{Selection and screening of ligand molecules}

One hundred natural compounds used as ligand molecules were taken from the National Centre for Biotechnology Information (NCBI) Pub-Chem database. These molecules were downloaded in Canonical SMILES format and converted to Protein Data Bank (PDB) coordinates file using Online SMILIS translate (http://cactus.nci.nih.gov/ translate/). The selected ligand molecules were checked through the Molinspiration online server (http://www. molinspiration.com/cgi-bin/properties) for identifying their drug-likeness properties, and only 89 molecules that obey the Lipinski's rule of five were used for further docking analysis (Table 2).

\subsubsection{Docking studies of natural inhibitors with GPR120 model}

Docking studies were performed to gain insight into the binding conformation of lead molecules with GPR120 model. A library of 100 lead molecules was constructed and screened for satisfying the minimal criteria of ADME for 


\section{Secondary structure summary}

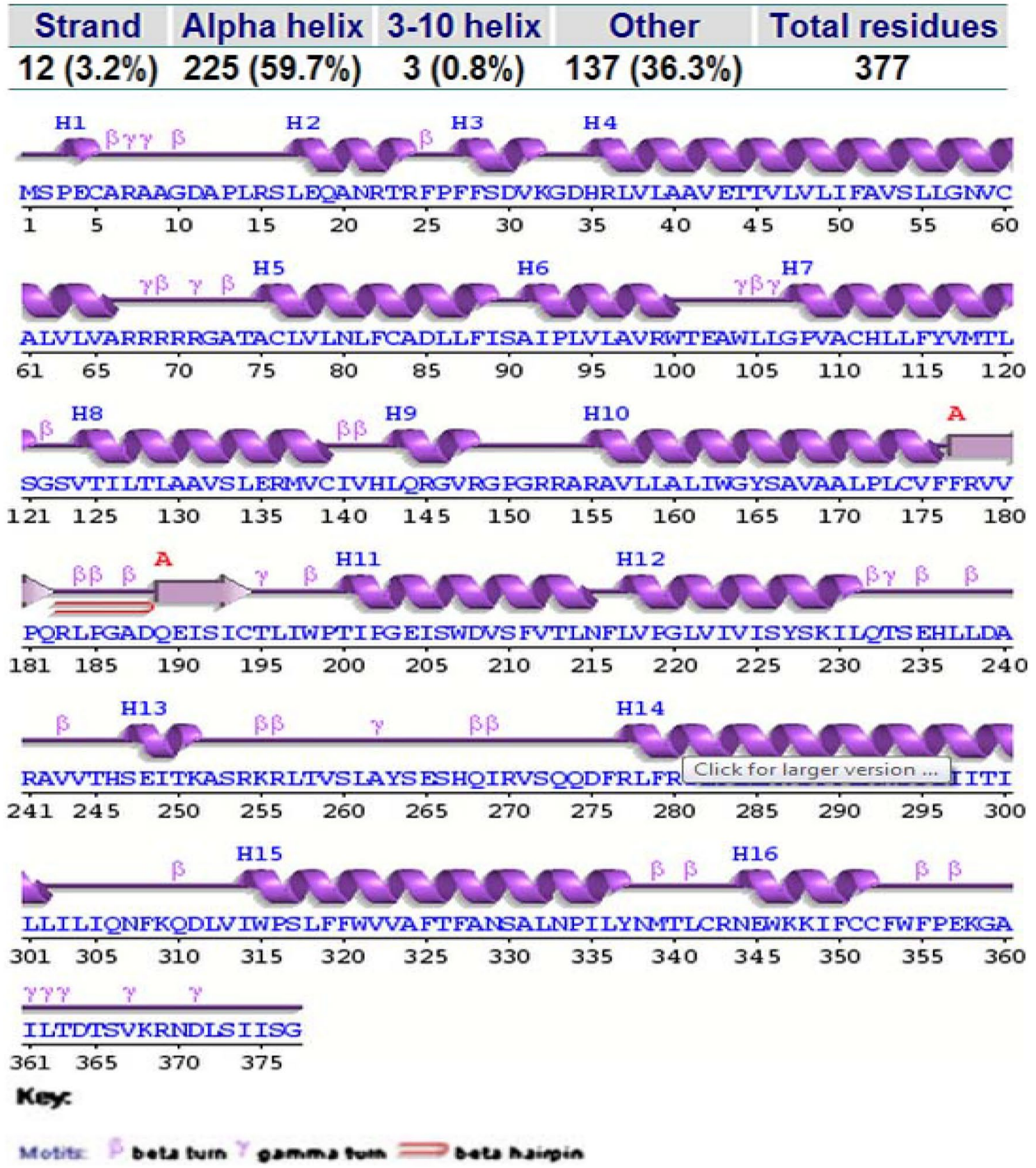

Fig. 4 Secondary structure wiring diagram for the GPR120 showing the location of secondary structure elements

further analysis, using molinspiration. Among the 100 lead molecules, 89 molecules were selected based on the criteria of satisfying Lipinski's rule of five with zero violations. All docking calculations were carried out using AutoDock 4.0/ADT and the dlg files generated were analyzed for their binding conformations. Analysis was based on free energy of binding, lowest docked energy, and calculated RMSD values (Table 3). The total clusters of docking conformations, with the 89 docked lead molecules, showed negative binding energies. Among all docking conformations, Silybin (Wing Ying Cheung et al. 2010), Withanolide D (Susmita Mondal et al. 2010), Limonene (Vigushin et al. 1998), and Carvacrol (Hailong et al. 2012), respectively, gave the best predicted binding-free energy of $-6.19,-6.87,-6.17$, and $-6.15 \mathrm{kcal} \mathrm{mol}^{-1}$ to the GPR120 (Fig. 5, Table 4), and the 
Table 2 Drug-like properties of natural compounds used in docking studies onto G-protein coupled receptor 120

\begin{tabular}{|c|c|c|c|c|c|c|c|c|}
\hline $\begin{array}{l}\text { S. } \\
\text { no. }\end{array}$ & $\begin{array}{l}\text { Name of } \\
\text { compound }\end{array}$ & $\begin{array}{l}\text { Structure of } \\
\text { compound }\end{array}$ & Mol. wt & $\begin{array}{l}\log p \\
\text { value }\end{array}$ & $\begin{array}{l}\text { H. } \\
\text { donor }\end{array}$ & $\begin{array}{l}\text { H. } \\
\text { ace- } \\
\text { ptor }\end{array}$ & TPSA & $\begin{array}{l}\text { Rot. } \\
\text { bonds }\end{array}$ \\
\hline 1 & $\begin{array}{l}\text { Guggulsterone } \\
\text { s E }\end{array}$ & & 312.453 & 3.62 & 0 & 2 & 34.14 & 0 \\
\hline 2 & Capsaicin & & 305.418 & 3.103 & 2 & 4 & 58.56 & 9 \\
\hline 3 & (-)Epicatechine & & 290.271 & 1.369 & 5 & 6 & 110.37 & 1 \\
\hline 4 & Epicatechingall & & 442.376 & 2.537 & 7 & 10 & 177.13 & 4 \\
\hline 5 & Eugenol & & 164.204 & 2.1 & 1 & 2 & 29.46 & 3 \\
\hline 6 & Eupatin & & 360.318 & 2.314 & 3 & 8 & 118.59 & 4 \\
\hline 7 & Gingerol & & 294.391 & 3.217 & 2 & 4 & 66.76 & 10 \\
\hline 8 & Isoeugenol & & 164.204 & 2.379 & 1 & 2 & 29.46 & 2 \\
\hline 9 & Limonene & & 136.238 & 3.615 & 0 & 0 & 0.0 & 1 \\
\hline
\end{tabular}


Table 2 (continued)

\begin{tabular}{|c|c|c|c|c|c|c|c|c|}
\hline 10 & Oliandrin & & 576.727 & 2.877 & 2 & 9 & 120.76 & 6 \\
\hline 11 & Quercetin & & 302.238 & 1.683 & 5 & 7 & 131.23 & 1 \\
\hline 12 & Triterpenoid & & 552.774 & 3.224 & 3 & 7 & 121.13 & 4 \\
\hline 13 & Betulinic acid & & 456.711 & 7.04 & 2 & 3 & 57.527 & 2 \\
\hline 14 & $\begin{array}{l}\text { Cinnamyl } \\
\text { acetate }\end{array}$ & & 176.215 & 2.736 & 0 & 2 & 26.30 & 4 \\
\hline 15 & Daidzein & & 254.241 & 2.559 & 2 & 4 & 70.66 & 1 \\
\hline 16 & Evodimine & & 303.365 & 2.819 & 1 & 4 & 39.33 & 0 \\
\hline 17 & Genistin & & 432.381 & 0.48 & 6 & 10 & 170.04 & 4 \\
\hline 18 & Paradol & & 278.392 & 4.602 & 1 & 3 & 46.53 & 10 \\
\hline 19 & $\begin{array}{l}\text { Yakuchinone- } \\
\text { A }\end{array}$ & & 312.409 & 4.241 & 1 & 3 & 46.53 & 9 \\
\hline
\end{tabular}


Table 2 (continued)

\begin{tabular}{|c|c|c|c|c|c|c|c|c|}
\hline 20 & Artemisine & & 282.336 & 3.316 & 0 & 5 & 54.07 & 0 \\
\hline 21 & Carvacrol & & 150.221 & 3.815 & 1 & 1 & 20.22 & 1 \\
\hline 22 & Catharanthine & & 366.435 & 3.987 & 1 & 4 & 45.33 & 3 \\
\hline 23 & $\begin{array}{l}\text { Phenolic } \\
\text { Steroid }\end{array}$ & & 256.389 & 4.58 & 1 & 1 & 20.22 & 0 \\
\hline 24 & Tabersonine & & 336.435 & 3.687 & 1 & 4 & 41.57 & 3 \\
\hline 25 & Citral & & 152.237 & 3.654 & 0 & 1 & 17.071 & 4 \\
\hline 26 & Caffeine & & 194.194 & 0.063 & 0 & 6 & 61.83 & 0 \\
\hline 27 & Rhein & & 284.223 & 2.997 & 3 & 6 & 111.89 & 1 \\
\hline 28 & Rubiadin & & 254.241 & 3.719 & 2 & 4 & 74.59 & 0 \\
\hline 29 & Taxifolin & & 304.254 & 0.712 & 5 & 7 & 127.44 & 1 \\
\hline 30 & Tyrosol & & 138.166 & 1.005 & 2 & 2 & 40.45 & 2 \\
\hline 31 & Viscidulin 11 & & 330.292 & 2.731 & 3 & 7 & 109.36 & 3 \\
\hline
\end{tabular}


Table 2 (continued)

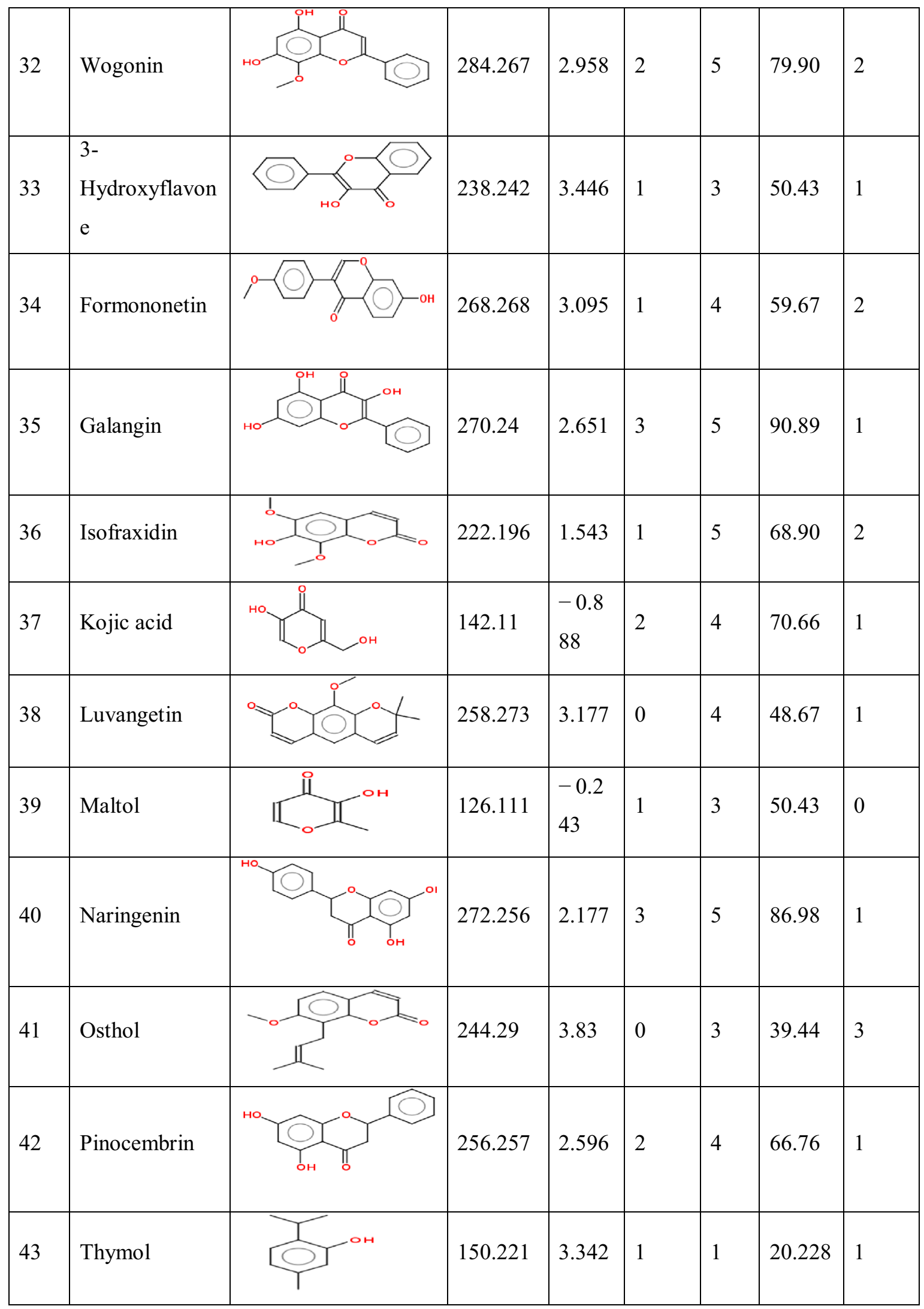


Table 2 (continued)

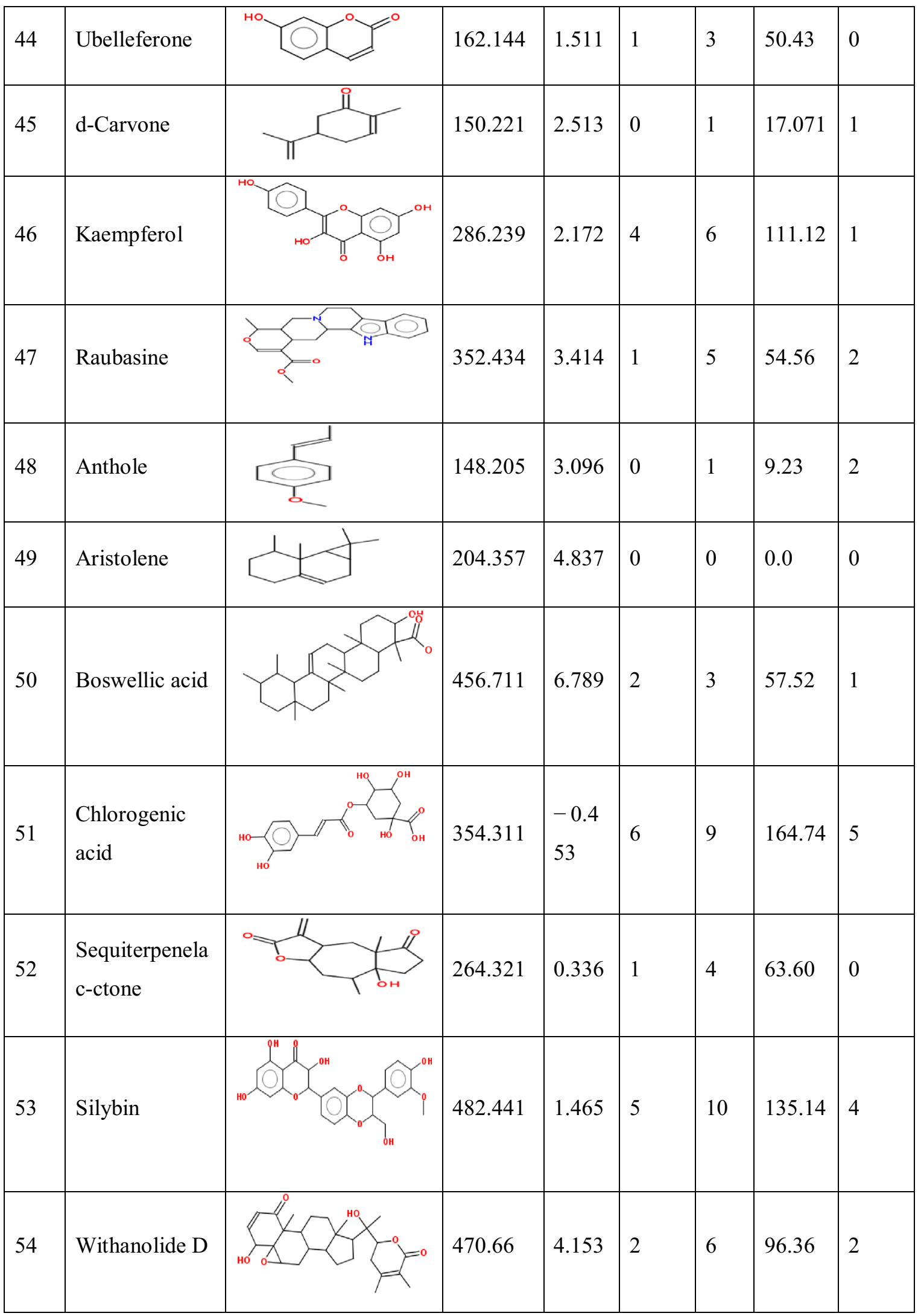


Table 2 (continued)

\begin{tabular}{|c|c|c|c|c|c|c|c|c|}
\hline 55 & Zerumbone & & 218.34 & 4.204 & 0 & 1 & 17.07 & 0 \\
\hline 56 & Asculetin & & 178.13 & 1.021 & 2 & 4 & 70.66 & 0 \\
\hline 57 & $\begin{array}{l}\text { Allylpyrocatec } \\
\text { hol }\end{array}$ & & 150.17 & 1.998 & 2 & 2 & 40.45 & 0 \\
\hline 58 & Ascabio & & 212.28 & 3.703 & 0 & 2 & 26.30 & 4 \\
\hline 59 & Aurapten & & 298.32 & 5.568 & 0 & 3 & 39.44 & 6 \\
\hline 60 & $\begin{array}{l}\text { Barcelonic } \\
\text { acid A }\end{array}$ & & 320.27 & 2.359 & 4 & 7 & 116.45 & 5 \\
\hline 61 & Bilobol & & 318.51 & 7.843 & 2 & 2 & 40.45 & 13 \\
\hline 62 & $\begin{array}{l}\text { Benzyl } \\
\text { glycopyranosid } \\
\text { e }\end{array}$ & & 270.21 & $\begin{array}{l}-0.4 \\
32\end{array}$ & 4 & 6 & 99.38 & 4 \\
\hline 63 & Chrysin & & 254.21 & 2.943 & 2 & 4 & 70.66 & 1 \\
\hline 64 & Cinchonine & & 294.38 & 3.028 & 1 & 3 & 36.35 & 3 \\
\hline 65 & Butin & & 272.256 & 1.711 & 3 & 5 & 86.98 & 1 \\
\hline
\end{tabular}


Table 2 (continued)

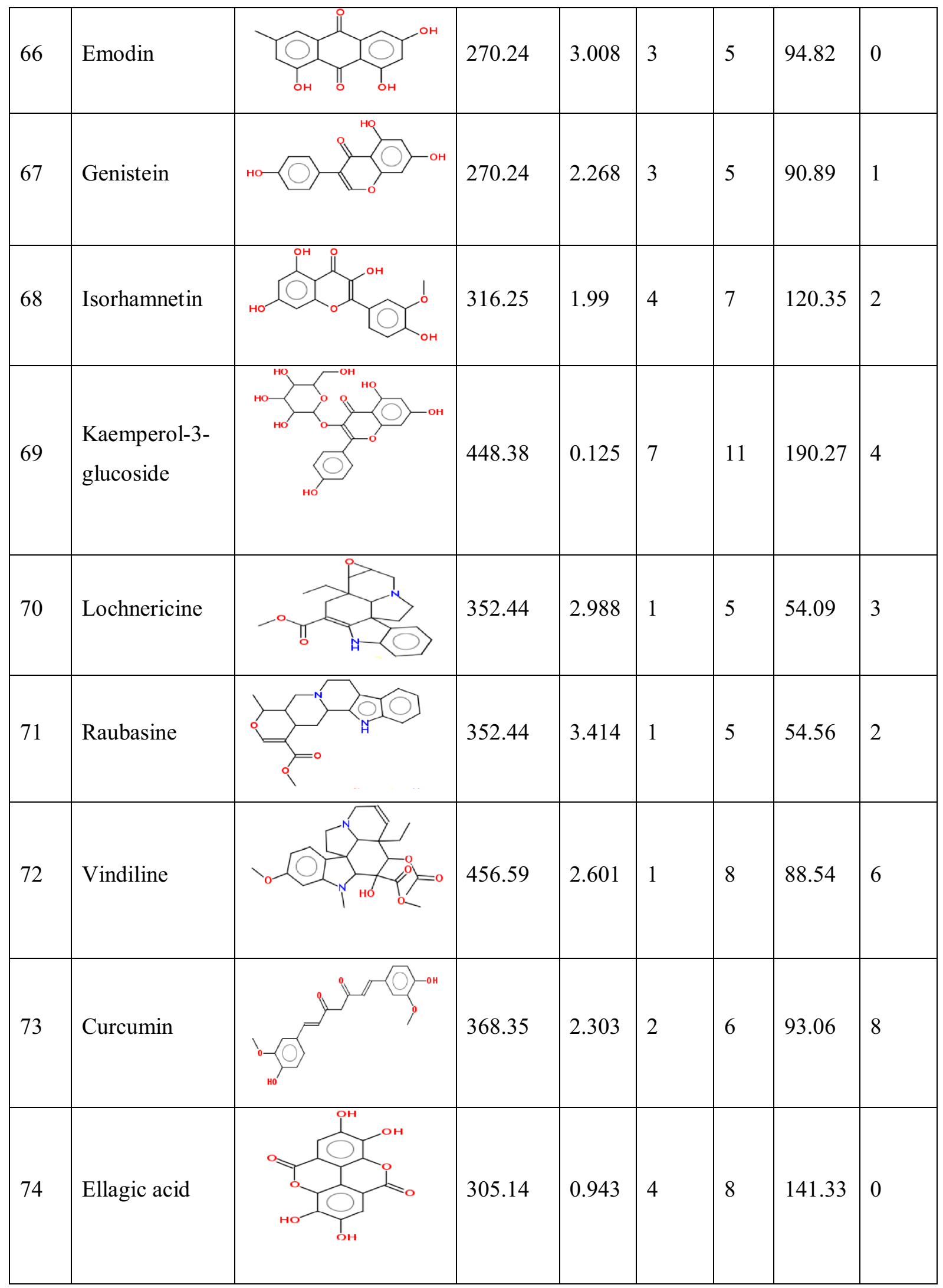


Table 2 (continued)

\begin{tabular}{|c|c|c|c|c|c|c|c|c|}
\hline 75 & Flavopiridol & & 401.86 & 3.455 & 3 & 6 & 94.13 & 2 \\
\hline 76 & $\begin{array}{l}\text { Indole-3- } \\
\text { cabinol }\end{array}$ & & 147.17 & 1.426 & 2 & 2 & 36.01 & 1 \\
\hline 77 & Linalool & & 154.23 & 3.213 & 1 & 1 & 20.22 & 4 \\
\hline 78 & $\begin{array}{l}\text { Haloginated } \\
\text { mono terpene }\end{array}$ & & 328.45 & 4.826 & 0 & 0 & 0.0 & 4 \\
\hline 79 & Oleanolic acid & & 456.71 & 6.725 & 2 & 3 & 57.52 & 1 \\
\hline 80 & Parthanolide & & 248.32 & 2.089 & 0 & 3 & 38.88 & 0 \\
\hline 81 & Resveratrol & & 228.27 & 2.986 & 3 & 3 & 60.68 & 2 \\
\hline 82 & Sulforafan & & 177.24 & 1.146 & 0 & 0 & 29.435 & 5 \\
\hline 83 & Ursolic acid & & 456.711 & 6.789 & 2 & 3 & 33.0 & 1 \\
\hline 84 & Biochanin A & & 284.267 & 2.804 & 2 & 5 & 79.90 & 2 \\
\hline
\end{tabular}


Table 2 (continued)

\begin{tabular}{|c|c|c|c|c|c|c|c|c|}
\hline 85 & Catharanthine & & 336.435 & 3.987 & 1 & 4 & 45.33 & 3 \\
\hline 86 & Z-PICEID & & 390.388 & 1.199 & 6 & 8 & 139.83 & 5 \\
\hline 87 & Alpinetin & & 270.284 & 2.664 & 1 & 4 & 55.76 & 2 \\
\hline 88 & Arbutin & & 272.253 & $\begin{array}{l}-0.8 \\
08\end{array}$ & 5 & 7 & 119.60 & 3 \\
\hline 89 & Carvone & & 150.221 & 2.513 & 0 & 1 & 17.07 & 1 \\
\hline 90 & Luteoin & & 286.239 & 1.974 & 4 & 6 & 111.12 & 1 \\
\hline 91 & Morin & & 302 & 1.881 & 5 & 7 & 131.35 & 1 \\
\hline 92 & Syrengic acid & & 198.174 & 1.204 & 2 & 5 & 75.99 & 3 \\
\hline 93 & $\begin{array}{l}\text { Benzyl } \\
\text { benzoate }\end{array}$ & & 212.248 & 3.703 & 0 & 2 & 26.305 & 4 \\
\hline 94 & Lusianthridine & & 242.274 & 2.04 & 2 & 3 & 49.69 & 2 \\
\hline
\end{tabular}


Table 2 (continued)

\begin{tabular}{|c|c|c|c|c|c|c|c|c|}
\hline 95 & Piperine & & 285.343 & 3.332 & 0 & 4 & 38.77 & 3 \\
\hline 96 & Anabasine & & 162.236 & 0.449 & 1 & 2 & 24.91 & 1 \\
\hline 97 & Isoferulic acid & & 194.186 & 1.249 & 2 & 4 & 66.76 & 3 \\
\hline 98 & Phloretin & & 274.272 & 2.656 & 4 & 5 & 97.98 & 4 \\
\hline 99 & Pinostrobin & & 270.284 & 3.132 & 1 & 4 & 55.76 & 2 \\
\hline 100 & Santin & & 344.319 & 3.0 & 2 & 7 & 98.36 & 4 \\
\hline
\end{tabular}

corresponding references clearly uncloak which are all under clinical trails.

To confirm the binding mode of natural substrate, docking was performed on the GPR120 model; natural substrate docking revealed that the amino acids Ile50 in orange, Phe88 in yellow, Ala91 in salmon, Gly122 in green, Ile191 in red, Asn215 in magenta, Asp275 in cyan, Arg280 in orange, Phe289 in salmon, Ile295 in yellow, Ile297 in spiltpea, Ile300 in salmon, Ile301 in yellow, and Phe325 in deepsalmon color (Fig. 5) played vital role to in binding the natural substrates and except Asn215, Asp275, and Arg280 all hydrophobic amino acids.

\section{Conclusion}

In this study, we have developed a three-dimensional structure of GPR120 receptor through homology modeling using delta opioid $7 \mathrm{tm}$ receptor (PDB ID: 4N6H) as a template. The generated model was assessed by several validation tools like Procheck, Errat, whatif, ProSA 2007, and Verify 3D. All above-mentioned tools revealed that the model is reliable. This model was also submitted to PMDB server (PDB: PM0079568) for public assessment. From the available scientific literature, 100 natural compounds have been selected and 89 compounds followed 
Table 3 Binding energies of docked natural compounds calculated by AutoDock

\begin{tabular}{|c|c|c|c|c|}
\hline S. no. & Compound name & CID no. & $\begin{array}{l}\text { Lowest binding energy } \\
(\mathrm{kcal} / \mathrm{mol})\end{array}$ & $\begin{array}{l}\text { Inhibition } \\
\text { constant }(\mu \mathrm{M} / \\
\mathrm{mM})\end{array}$ \\
\hline 1 & Guggulsterones E & 6439929 & -4.44 & 73.25 \\
\hline 2 & Capsacian & 1548943 & -4.42 & 553.27 \\
\hline 3 & (-)Epicatechine & 72276 & -4.57 & 447.16 \\
\hline 4 & Euenol & 3314 & -3.8 & 308.86 \\
\hline 5 & Flavonoid & 5317287 & -5.05 & 16.30 \\
\hline 6 & Gingerol & 442793 & -3.86 & 20.13 \\
\hline 7 & Isoeugenol & 853433 & -5.4 & 110.45 \\
\hline 8 & Limonene & 22311 & -6.17 & 29.84 \\
\hline 9 & Quercetin & 5280343 & -4.41 & 583.29 \\
\hline 10 & Cinnamyl acetate & 5282110 & -6.05 & 36.67 \\
\hline 11 & Daidzein & 5281708 & -5.25 & 141.64 \\
\hline 12 & Evodimine & 151289 & -5.0 & 215.46 \\
\hline 13 & Paradol & 94378 & -3.99 & 11.90 \\
\hline 14 & Yakuchinone-A & 133145 & -4.35 & 651 \\
\hline 15 & Artemisine & 68827 & -5.24 & 144.17 \\
\hline 16 & Carvacrol & 10364 & -6.15 & 30.87 \\
\hline 17 & Catharanthine & 197771 & -5.48 & 96.85 \\
\hline 18 & Phenolic steroid & 439726 & 4.71 & 354.94 \\
\hline 19 & Tabersonine & 20485 & -5.53 & 88.58 \\
\hline 20 & Citral & 643779 & -4.95 & 235.43 \\
\hline 21 & Caffeine & 2519 & -3.41 & 3190 \\
\hline 22 & Rhein & 10168 & -4.7 & 359.53 \\
\hline 23 & Rubiadin & 124062 & -4.53 & 477.98 \\
\hline 24 & Taxifolin & 439533 & -4.68 & 373.32 \\
\hline 25 & Tyrosol & 10393 & -4.63 & 400.67 \\
\hline 26 & Viscidulin 11 & 5322059 & -5.35 & 120.69 \\
\hline 27 & Wogonin & 5281703 & -5.27 & 137.15 \\
\hline 28 & 3-Hydroxyflavone & 11349 & -5.07 & 192.3 \\
\hline 29 & Formononetin & 5280378 & -4.39 & 608.88 \\
\hline 30 & Galangin & 5281616 & -4.78 & 315.78 \\
\hline 31 & Isofraxidin & 5318565 & -4.21 & 818.78 \\
\hline 32 & Kojic acid & 3840 & -4.56 & 457.88 \\
\hline 33 & Luvangetin & 343582 & -457 & 446.42 \\
\hline 34 & Maltol & 8369 & -4.2 & 829.62 \\
\hline 35 & Naringenin & 932 & -4.84 & 284.29 \\
\hline 36 & Osthol & 10228 & -4.87 & 268.85 \\
\hline 37 & Pinocembrin & 68071 & -5.25 & 141.93 \\
\hline 38 & Thymol & 6989 & -3.5 & 320 \\
\hline 39 & Ubelleferone & 5281426 & -5.98 & 41.05 \\
\hline 40 & D-Carvone & 16724 & -5.63 & 75.18 \\
\hline 41 & Kaempferol & 5280863 & -4.42 & 75.18 \\
\hline 42 & Raubasine & 441975 & -5.13 & 173.58 \\
\hline 43 & Anthole & 637563 & -4.1 & 991.37 \\
\hline 44 & Aristolene & 530421 & -5.41 & 107.8 \\
\hline 45 & Sequiterpenelacctone & 338659 & -5.58 & 81.2 \\
\hline 46 & Silybin & 31553 & -6.87 & 9.12 \\
\hline 47 & Withanolide D & 161671 & -6.19 & 78.71 \\
\hline 48 & Zerumbone & 5470187 & -3.7 & 1860 \\
\hline 49 & Asculetin & 5281416 & -4.51 & 496.78 \\
\hline
\end{tabular}


Table 3 (continued)

\begin{tabular}{|c|c|c|c|c|}
\hline S. no. & Compound name & CID no. & $\begin{array}{l}\text { Lowest binding energy } \\
(\mathrm{kcal} / \mathrm{mol})\end{array}$ & $\begin{array}{l}\text { Inhibition } \\
\text { constant }(\mu \mathrm{M} / \\
\mathrm{mM})\end{array}$ \\
\hline 50 & Allylpyrocatechol & 292101 & 5.09 & 185.5 \\
\hline 51 & Ascabiol & 2345 & -4.51 & 496.78 \\
\hline 52 & Barcelonic acid A & 10358625 & -3.73 & 18.60 \\
\hline 53 & Bilobol & 5281852 & -2.97 & 1.86 \\
\hline 54 & Benzyl glycopyranoside & 188977 & -4.24 & 782.76 \\
\hline 55 & Chrysin & 5281607 & -4.81 & 297.75 \\
\hline 56 & Cinchonine & 90454 & -4.89 & 260.15 \\
\hline 57 & Butin & 92775 & -5.57 & 82.55 \\
\hline 58 & Emodin & 3220 & -4.62 & 409.35 \\
\hline 59 & Genistein & 5280961 & -5.64 & 73.25 \\
\hline 60 & Isorhamnetin & 5281654 & -4.96 & 0.21 \\
\hline 61 & Kaemperol-3-glucoside & 5282102 & -4.42 & 571.91 \\
\hline 62 & Lochnericine & 11382599 & -5.19 & 156.7 \\
\hline 63 & Raubasine & 441975 & 5.11 & 179.54 \\
\hline 64 & Vindiline & 260535 & -5.92 & 45.74 \\
\hline 65 & Curcumin & 969516 & -5.06 & 196.36 \\
\hline 66 & Flavopiridol & 5287969 & -3.98 & 1210 \\
\hline 67 & Indole-3-cabinol & 3712 & -3.53 & 2600 \\
\hline 68 & Linool & 6549 & 3.53 & 2590 \\
\hline 69 & Haloginated mono terpene & 11493622 & -4.45 & 544.66 \\
\hline 70 & Parthanolide & 6473881 & -4.92 & 248.68 \\
\hline 71 & Resveratrol & 445154 & -5.76 & 59.59 \\
\hline 72 & Sulforafan & 5350 & -4.82 & 290.63 \\
\hline 73 & Biochanin A & 5280373 & -4.96 & 232.7 \\
\hline 74 & Catharanthine & 197771 & -5.58 & 0.22 \\
\hline 75 & Z-PICEID & 10178463 & -5.72 & 63.73 \\
\hline 76 & Alpinetin & 4053302 & -4.92 & 245.55 \\
\hline 77 & Arbutin & 440936 & -5.04 & 202.08 \\
\hline 78 & Carvone & 7439 & -5.27 & 137.55 \\
\hline 79 & Luteoin & 5280445 & -5.76 & 60.28 \\
\hline 80 & Morin & 5281670 & -4.3 & 705.91 \\
\hline 81 & Syrengic acid & 10742 & -3.27 & 4030 \\
\hline 82 & Benzyl benzoate & 2345 & -6.41 & 19.92 \\
\hline 83 & Lusianthridine & 442702 & -3.72 & 1.88 \\
\hline 84 & Piperine & 638024 & -4.59 & 432.06 \\
\hline 85 & Anabasine & 2181 & -5.69 & 67.14 \\
\hline 86 & Isoferulic acid & 736186 & -5.8 & 80.97 \\
\hline 87 & Phloretin & 4788 & -3.72 & 1890 \\
\hline 88 & Pinostrobin & 73201 & -5.29 & 132.4 \\
\hline 89 & Santin & 5281695 & -4.91 & 251.48 \\
\hline
\end{tabular}

the rule of five. These 89 natural compounds were docked with GPR120 receptor and the following four compounds have exhibited the highest binding energy levels in the order as CID: 31553 > CID: 161671 > CID: 22311 > CID: 10364, which infers the favorable rank score, docking score, and hydrogen-bonding energies. Furthermore, 


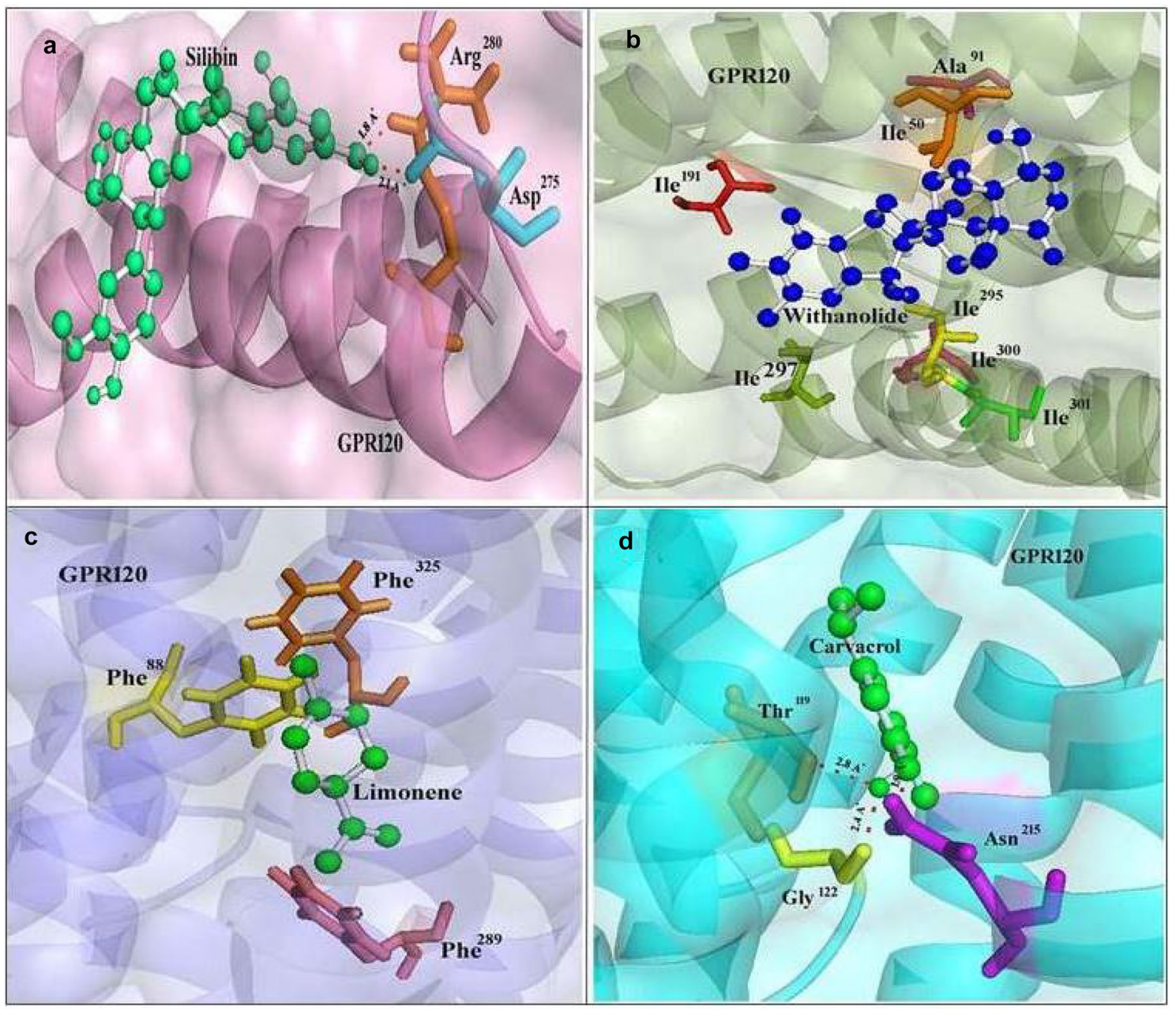

Fig. 5 a Docking conformation of natural compound of Sylibin on G-protein coupled receptor 120 homology model. b Docking conformation of natural compound of Withanolide on G-protein coupled receptor 120 homology model. c Docking conformation natural compound of limonene on G-protein coupled receptor 120 homology model. d Docking conformation of natural compound of carvacrol on G-protein coupled receptor 120 homology models. Built model of G-protein coupled receptor 120 is represented in cartoon and $60 \%$ of electrostatic surface. Ligands are represented by ball and stick and the residues interacting with are represented by stics
Table 4 High score-binding energies of docked natural compounds calculated by AutoDock

\begin{tabular}{lccccc}
\hline Docked molecule & Compound Cid no. & Cluster rank & $\begin{array}{l}\text { Cluster } \\
\text { number }\end{array}$ & $\begin{array}{l}\text { Binding energy } \\
\text { (kcal/mol) }\end{array}$ & RMSD (̊) \\
\hline Silybin & 31553 & 1 & 3 & -6.87 & 0.49 \\
Withanolide D & 161671 & 1 & 3 & -6.19 & 0.82 \\
Limonene & 22311 & 2 & 41 & -6.17 & 0.13 \\
Carvacrol & 10364 & 1 & 19 & -6.15 & 0.65 \\
\hline
\end{tabular}

more hydrophobic interactions were observed in the binding pocket of the GPR120. These four drugs are under clinical trials and thereby help promising therapeutics for colorectal cancer.
Acknowledgements This work was supported by Department of Biotechnology (DBT) Bioinformatics Infrastructure Facility (BIF) and a Fellowship from Indian Council of Medical Research (ICMR), Govt. of India, New Delhi (to SC). 


\section{Compliance with ethical standards}

Conflict of interest The authors declare that no conflicts of interest exist.

Open Access This article is distributed under the terms of the Creative Commons Attribution 4.0 International License (http://creativeco mmons.org/licenses/by/4.0/), which permits unrestricted use, distribution, and reproduction in any medium, provided you give appropriate credit to the original author(s) and the source, provide a link to the Creative Commons license, and indicate if changes were made.

\section{References}

Abdul Khalek FJ, Gallicano GI, Mishra L (2010) Colon cancer stem cells. Gastrointest Cancer Res S16-S23

Altshul SF, Madden TL, Schaffer AA, Zhang J, Zhang W, Mille W, Lipman D (1997) Gapped BLAST and PSI BLAST-a new generation of protein data base search programs. J Nucl Acids Res 25:3389-3402

American Cancer Society (2015) Cancer facts and figures. Atlanta. Available online

Berjanskii MV, Neal S, Wishart DS (2006) PREDITOR a web server for predicting torsion angle restraints. Nucl Acids Res 34:W63-W69

Berman HM, Westbrook J, Feng Z, Gilliland G, Bhat TN, Weissig H, Shindyalov IN, Bourne PE (2000) The Protein Data Bank. Nucl Acids Res 28:235-242

Bertorelle R, Rampazzo E, Pucciarelli S, Nitti D, De Rossi A (2014) Telomeres, telomerase and colorectal cancer. World J Gastroenterol 28(20):1940-1950

Bowie JU, Luthy R, Eisenberg D (1991) A method to identify protein sequences that fold into a known three-dimensional structure. Science 253:164-170

Castrignano T, De Meo PDO, Cozzetto D, Talamo IG, Tramontano A (2006) The PMBD Protein Model Database. Nucl Acids Res 34:306-309

Colovos C, Yeates TO (1993) Verification of protein structure: patterns of nonbonded atomic interactions. Protein Sci 2:1511-1519

Dorsam RT, Gutkind JS (2007) G-protein coupled receptors and cancer. Nat Rev Cancer 7:79-94

Farnsworth NR, Akerele O, Bingel AS, Soejarto DD, Guo Z (1985) Medicinal plants in therapy. Bull World Health Organ 63:965-981

Feigin ME (2013) Harnessing the genome for characterization of G-protein coupled receptors in cancer pathogenesis. FEBS J 280(19):4729-4738

Fenalti G, Giguere PM, Katritch V, Huang XP, Thompson AA, Cherezov V, Roth BL, Stevens RC (2014) Molecular control of $\delta$-opioid receptor signalling. Nature 506(7487):191-196

Gether U (2000) Uncovering molecular mechanisms involved in activation of G protein-coupled receptors. Endocr Rev 21:90-113

Goodsell DS, Morris GM (1998) Automated docking using a Lamarckian genetic algorithm and an empirical binding free energy function. J Comput Chem 19(14):1639-1662

Guex N, Peitsch MC (1997) SWISS MODEL and the Swiss PDB viewer: an environment for comparative protein modeling. Electrophoresis 18:2714-2723

Hartwell JL (1971) Plants used against cancer a survey. Lloydia 34(4):386-425

http://www.salilab.org/modeller/9v3

Ichimura A, Hirasawa A, Poulain-Godefroy O, Bonnefond A, Hara T, Yengo L (2012) Dysfunction of lipid sensor GPR120 leads to obesity in both mouse and human. Nature 483:350-354
Ionov Y, Peinado MA, Malkhosyan S, Shibata D, Perucho M (1993) Ubiquitous somatic mutations in simple repeated sequences reveal a new mechanism for colonic carcinogenesis. Nature 363(6429):558-561

Kitchen DB, Decornez H, Furr JR, Bajorath J (2004) Docking and scoring in virtual screening for drug discovery-methods and applications. Nat Rev Drug Discov 3:935-949

Lappano R, Maggiolini M (2011) G-protein coupled receptors Novel targets for drug discovery in cancer. Nat Rev Drug Discov 10:47-60

Laskowski RA, MacArthur MW, Moss DS, Thornton JM (1993) PROCHECK a program to check the stereo chemical quality of protein structure. J Appl Crystallogr 26:283-291

Laskowski RA, Watson JD, Thornton JM (2005) ProFunc a server for predicting function from 3D structure. Nucl Acids Res 33:W89-W93

Lipinski CA, Lombardo F, Dominy W, Feeney PJ (2001) Experimental and computational approaches to estimate solubility and permeability in drug discovery and development settings. Adv Drug Deliv Rev 46:3-26

Luthy R, Bowie JU, Eisenberg D (1992) Assessment of protein models with three-dimensional profiles. Nature 356:83-85

Miyamoto S, Kollman PA (1992) SETTLE an analytical version of the SHAKE and RATTLE algorithms for rigid water models. J Comput Chem 13:952-962

Mondal S, Mandal C, Sangwan R, Chandra S, Mandal C (2010) Withanolide $\mathrm{D}$ induces apoptosis in leukemia by targeting the activation of neutral sphingomyelinase-ceramide cascade mediated by synergistic activation of c-Jun N-terminal kinase and p38 mitogenactivated protein kinase. Mol Cancer 5(5):239

Morris AJ, Malbon CC (1999) Physiological regulation of G proteinlinked signaling. Physiol Rev 79:1373-1430

NCBI. http://www.ncbi.nlm.nih.gov/

Oh DY, Talukdar S, Bae EJ, Imamura T, Hidetaka Morinaga W, Fan Q, Li P, Lu WJ, Watkins SM, Olefsky JM (2010) GPR120 is an omega-3 fatty acid receptor mediating potent anti-inflammatory and insulin sensitizing effects. Cell 142(5):687-698

Oprea TI, Davis AM, Teague SJ, Leeson PD (2001) Is there a difference between leads and drugs? A historical perspective. J Chem Inf Comput Sci 41:1308-1315

Rajesh E, Sankari LS, Malathi L, Krupaa JR (2015) Naturally occurring products in cancer therapy. J Pharm Bioallied Sci 7(Suppl 1):S181-S183

Schulte G, Fredholm BB (2003) Signaling from adenosine receptors to mitogen-activated protein kinases. Cell Signal 15:813-827

Shike M, Winawer SJ, Greenwald PH (1990) Primary prevention of colorectal cancer. The WHO Collaborating Centre for the Prevention of Colorectal Cancer. Bull World Health Organ 68(3):377-385

Sippl MJ (1993) Recognition of errors in three-dimensional structures of proteins. Proteins 17:355-362

Surh YJ (2003) Cancer chemoprevention with dietary phytochemicals. Nat Rev Cancer 3(768-780): 14

Thompson JD, Higgins DG, Gibson TJ (1994) Clustal W-improving the sensitivity of progressive multiple sequence alignment through sequence weighting position-specific gap penalties and weight matrix choice. Nucl Acids Res 22:4673-4680

Ulloa-Aguirre A, Stanislaus D, Janovick JA, Conn PM (1999) Structure-activity relationships of $\mathrm{G}$ protein-coupled receptors. Arch Med Res 30:420-435

Vigushin DM, Poon GK, Boddy A, English J, Halbert GW, Pagonis C, Jarman M, Coombes RC, Cancer Research Campaign Phase I/ II Clinical Trials Committee (1998) Phase I and pharmacokinetic study of D-limonene in patients with advanced cancer. Cancer Chemother Pharmacol 42(2):111-117 
Vriend G (1990) WHATIF-a molecular modeling and drug design program. J Mol Graph 8:52-56

Wing Ying Cheung C, Gibbons N, Wayne Johnson D, Lawrence Nicol D (2010) Silibinin-a promising new treatment for cancer. Anti Cancer Agents Med Chem 10(3):186-195

Wu Q, Wang H, Zhao X, Shi Y, Jin M, Wan B, Xu H, Cheng Y, Ge H, Zhang Y (2013) Identification of G-protein coupled receptor 120 as a tumor promoting receptor that induces angiogenesis and migration in human colorectal carcinoma. Oncogene 32:5541-5550

Yu H, Zhang Z-L, Chen J, Pei A, Hua F, Qian X, He J, Liu C-F, Xu $X$ (2012) Carvacrol a food additive provides neuroprotection on focal cerebral ischemia/reperfusion injury in mice. PLoS ONE 7(3):e33584 